\title{
The Impact of Social Media on Public Relations Practices among Information Officers in CAMANAVA and Batangas Philippines
}

\author{
Dr. Macario G. GAYETA \\ University of the East, Caloocan City, Metro Manila, Philippines \\ \{doc.aiyo@gmail.com\}
}

\begin{abstract}
Social media has dramatically increased public relations practices among public information officials that support various activities in local government units. The new media wave has great potential to make public relations more global, and strategic communication is more useful and can spread across a wide range of government public relations. The aim of this study is to examine the impact of social media on public relations, to identify the impact of public relations on information officers and to determine the use of social media impacts on the lives of information officers in local government units. The method used in this study is a quantitative method with an approximate coefficient of correlation. The results of this study found that the overall impact of social media on public relations practices relied on by public information officials in local government units who agree on indicators showed that social media gives more access to contacting friends and relatives and becomes a daily companion to communication activities. Information officers often use social media to share and send messages to clients, friends and followers of local government units. Information practices improve in terms of internal relations with local governments and also enhance the use of social media while maintaining their role as public servants. There is a significant correlation between the impact of social media on public relations between public information officials and the accepted hypothesis. The findings and recommendations are included in this study.
\end{abstract}

Keywords: Social Media; Public Relations; One-Way Communication; Information Officers

\section{Introduction}

The objective of this study was to investigate the impact of social media on the public relations practices of information officers in CAMANAVA and Batangas, Philippines. Specifically, the objective is to examine the impact of social media on public relations activities; to identify the impact of public relations practices; to determine the extent to which the use of social media has an impact on the personal lives of public information officers in local government units. 
The enormous impact of social media has been very dramatic in terms of its media platforms. Social media has been transformed into an integrated part of human communication, both of which serve as persuasive communication, social relations, sharing and information generation for the public. Several studies on the impact of social media have specifically explored public relations in local government units around the world (LGUs). New media has created a new form of communication, interacting mainly in the business world, which has also increased trust in the public sector [1], [2].

The pattern of corporate communication in social media has gradually changed in terms of disseminating information to the public, how new media have been formulated and how it is measured in terms of public engagement through its medium [3]. Social media has changed its platforms, and the way in which it evolves to facilitate the impact of public relations information officers is a much-discussed concern among constituents. However, James Grunig, a public relations theorist, emphasized that social media is the latest fashion that has revolutionized the role of public relations if stakeholders and scholars have already followed a new paradigm shift in public relations [4].

According to a scholar [5], a number of government agencies have adopted social technologies to serve the people of the population. The re-engineering of government sectors, from a traditional to a modern model, has attracted attention and gradually developed government transparency and trust, created citizen participation and civic engagement, and cooperated social media practices between the people and the government sector. Researchers [6] explain the meaning of social media as an online tool designed and developed around social interaction between individuals. Social media also refers to wave-based technologies and other online services such as blogs, microblogs (Twitter), social sharing (YouTube, Flickr, Pinterest, Tumblr), text messaging, forums, editing tools (wikis, RSS feeds, message boards [7], [8], virtual worlds, and social networking sites such as Facebook and MySpace) [9]. This set of online tools share common knowledge that allows users to communicate, interact, edit and share content in a social environment called social media.

Social media enables public relations organizations to engage in twoway communication in order to receive immediate feedback from the public sector [10]. Social media has become an alternative Internet solution for all Filipino online users. But Scholars [11] has revealed that social media can hinder rather than facilitate the delivery of goods and services. Statistically, the Internet population in the Philippines is made up of $80 \%$ of social media users, such as Facebook, Twitter, Tumbler and Pinterest. Facebook has become the most popular of the Philippines due to its cheapest access to mobile networks in the Philippines (Foundation for Media Alternatives, 2015) [12].

This research seeks to increase understanding of the impact of social media on public relations practices by examining the existing body of knowledge. The study will also examine the impact of social media on public relations practices, identify aspects of public relations practice and how the use of social media affects the personal lives of public information officers in local government units through social media. A review of the literature on social media will be reviewed, the use of social media will be described and social media communications will be discussed. The conclusion drawn in this study is advantageous for future researchers and local government units, organizations and practitioners as it determines the importance of social media to the practice of public relations in local government units (LGUs). 


\section{Literature Review}

\subsection{Public Relations Models}

Two scholars, James E. Grunig of the University of Maryland, USA, and Todd Hunt of Rutgers University, New Jersey, USA, have identified communication models in public relations by developing four models of public relations (PR) introduced in 1984 in the book "Managing Public Relations." The work of Grunig and Hunt recommended that public relations require both sides to achieve the objectives and objectives of an organization that could always predict the growth of public trust in government and personal interests. The definition of public relations and social media terms for Grunig and Hunt is as follows: 1. Press agent or advertisement model. The Press Agent is a one-way asymmetric model, a oneway communication pattern between the organization and the public.

This model uses persuasion and manipulation to influence and convince audiences to follow organizational expectations by spreading emotional messages that attract attention and interest. 2. The public information model. Public information is a one-way symmetrical model for organizations to focus more on delivering selected information to the public, trying to deliver accurate and material messages. This model uses a type of press release and similar techniques to deliver messages and information, while those PR practitioners are often referred to as inhouse journalists. 3. A two-way asymmetrical model. This model uses twoway communication patterns by paying attention to public feedback, but more directly by influencing the public to adjust to the organization, not vice versa (imbalanced). This model also uses persuasion to influence audiences, but does not use research to determine the wishes of the organization's stakeholders.

This model is shown on Twitter by collecting information from the public and then using it to develop messages that will be forwarded back to the public. 4. Two-way symmetrical model. This model uses a two-way communication pattern that uses communication to negotiate, resolve conflicts and build mutual understanding between organizations and stakeholders. This model is an ideal public relations model because it gives priority to dialog with the public and focuses on building relationships and mutual understanding, an excellent public relations theory (Nurfurqonah, Rahmanto, \& Hastjarjo, 2019). This also recognizes that city and local officials have encountered so many obstacles in operating within different study structures. The role of government agencies in the Philippines reflects their advancement in the public service through the advent of information and communication technologies, in which social media plays an important role and power among its users, taking a responsible step towards the role of people and collaboratively enhancing their participatory communication in the public service.

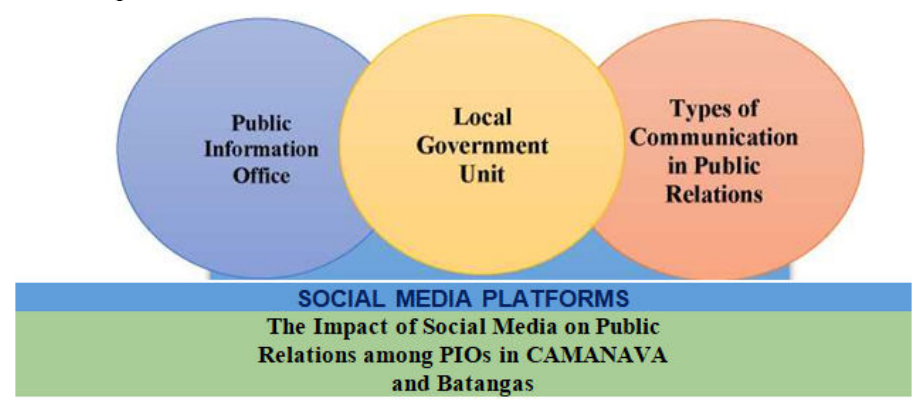

Fig. 1. The Framework of the Study 


\subsection{The Concept of Local Government Public Relations}

Through the enactment of the 1991 Local Government Code for Local Government Units, the concept of local government was born in order to improve the management functions and to put the plan into practice in order to facilitate the objectives of establishing administrative units in the local department, specifically the Public Information Officer and Community Affairs in each city and municipality.

Caloocan City. In the four cities of the district of CAMANAVA, the local government of Caloocan City is committed to public service through the City Public Affairs and Information Office, which aims at bridging the communication gap between the City Government and its stakeholders through the dissemination of information on the programs and projects of the Caloocan City Government towards the achievement of a productive education system. At the City Public Affairs and Information Office (CPAIO), the City of Caloocan maintains a website where it publishes the latest news and vital information on the city government and updates for public consumption and dissemination.

The website of the Caloocan City Government has been awarded the Philippine Transparency Seal for its public service commitment to the people called "Tao and Muna" or Citizens' First. The Town Government also maintains a Facebook account for updates, opinions, complaints and emergency services. They also have public commitments on social media, e-magazines, news releases, and media updates. CPAIO has a periodical and newspaper publication to disseminate the reports of the City Mayor and members of the City Council. The City Government also set up the Information Technology Office and maintained city government websites for the IT department.

Malabon City. The Public Information Office under the City Mayor's Office has confirmed that the use of social media in public offices is a good sign that Malabon City is pushing to disseminate information properly in order to reach out to residents. In addition, people need to be strong and committed as well as engaging, because social media is an effective and useful channel for citizen engagement in public relations. According to researchers [14], the power of community development has come to bear on the power of social media. The local government of Malabon has launched the Malabon Online Information Center to maintain the operation of its website and communication system.

The aim of the website of the online information center [15] is to disrupt the red tape of the local government unit in order to improve the delivery system to the public and to provide basic information to the public and provide guidance to citizens on the services offered by the Malabon City Government. Online news is also the driving force behind city government projects and other developments. The release of Malabon News (print) is also part of the dissemination of information to the city, which is vital to the management and collection of information in decision-making. Facebook and Twitter are the social media platforms used by Malabon LGU to reach people with 903 tweets and 9,820 followers in the area during the disaster. The Malabon Online Information Center shall be duly maintained by the MIS Department of Malabon City.

Navotas City. In disseminating information through social media platforms, Twitter becomes a channel for public and citizen engagement between the Navotas City Government and its people. The City of Navotas City launched the "Navoteno Ako" battle cry in the official Facebook account of the Public Information Office. Meanwhile, the City Mayor's Office and its Twitter account Navotas City (@Navotas City) has reached more than 7,254 Tweets with 17,600 followers and serves as the official Twitter account of the Navotas City Government [16]. 
In addition, Facebook could be written in a long space with no limitation on posting, and Twitter is very limited with no more than twenty words and supported by a picture to be posted to create more impact and tweets among its constituents in times of emergency and disaster. It is very interesting to know and to find out that local government legislators in Navotas City intend to provide sufficient funding to take into account appropriate information and communication technology (ICT) funds in the locality to exchange ideas and dialogs with locals, to disseminate information and to emphasize priority programs in the government.

Valenzuela City. Press releases and other achievements of the City Government are part of the PIO Team, which has published online news. The Official Website of the City Government of Valenzuela includes five pillars of good governance, focusing on public needs such as quality education, people's health and social welfare services, low-cost housing, job vacancies and small and medium-sized enterprises [17]. Social media platforms such as Facebook, Twitter and Instagram are being used to disseminate information to their constituents. Each category on the LGU online platform serves as a guide for people on-line to search for relevant and quality information.

The City Mayor has produced several innovative programs designed to enhance novelty and practical application in the promotion of good governance through world-class projects and highly sophisticated public welfare facilities. Valenzuela City is also considered to be a world-class local government that has earned a number of citations such as city economic accountability, resilience and disaster preparedness, outstanding employment and microentrepreneurship development programs, health and social protection policies, and the sound implementation of peace and order advocacy [18].

\subsection{Concept of Public Information in the Lone Districts}

Batangas Province has adapted the realities by exploring a new way of managing information through the help of De La Salle College in Lipa City back in 2018, which published a case study and part of the book was written. According to [19] data and information storage, retrieval and access were derived from the implementation of ICM in Batangas, which was facilitated by operational integrated information systems (IIMS).

Batangas City. For example, computer technology was used at the Public Information Office in Batangas City in 1995 to transform local government units operating under the Office of City Mayor Angelito B. Dimacuha. The initiative of the former mayor and his leadership led to the digitization of the Batangas City Government initiative and, during the administration of Atty, Eduardo B. Dimacuha, the City Mayor's Office, initiated several projects in the local government units in 1998 (LGUs). Efforts have been initiated by both administrations to make LGUs more accessible and open to public consumption.

These projects, however, sought to engage locals actively through information technology and to gather feedback as part of a government initiative. The PIO is composed of seven divisions, such as social media, print and photo, television and video production, radio broadcasting, special projects, audio and video, and administrative divisions under the Office of the Mayor. It shall be duly supervised by the City Administrator and the Supervisory Administrative Officer. Based on the website, Batangas City PIO uses social media platforms such as Facebook and Twitter to disseminate information with 117,000 likes. The local government initiative provides free legal assistance and free registration of land titles to those with problems in their parcel of land[20].

Lipa City. Social media use has grown dramatically around the world as a result of media convergence through Facebook and Twitter[21]. Lipa City is now classified as a lone district 
and the 6th district of the Province of Batangas, and communication and coordination with constituents is becoming hassle-free through social media platforms such as Facebook, Twitter and the City Government website. The Public Information Office has achieved the promotion of effective information management through social media. De La Salle College Lipa and the Lipa City Government have benefited from the project by expanding community outreach programs and developing research on the data generated by the system. To facilitate online discussion between DLSL and PIO and their constituents, they have launched a Facebook page and a group chat, and have maintained a partnership to date.

\subsection{The Concept of Social Media and Public Relations}

Researchers [22] examine the impact of social media on public relations practices in the public broadcasting network. The authors found that social media has had a huge impact on public relations practice; an opportunity to reach a large part of society's target audience even in remote villages without further delay in service in Nigeria. Researchers [23] found that of 458 respondents from professional communicators, the professional use of YouTube, social media, communications, and other related social marketing strategies was significant for the respondents' assessment of the use of social media.

The findings also show that the use of Facebook and YouTube in strategic communication, environmental scanning has a positive and negative impact on the use of social media has been significant among public relations professional leadership behaviours. However, public relations practitioners have been reported on their findings that there is a high level of worklife conflict in the extensive use of social media. Researchers [24] found that the use of social media has not yet been hindered by local government units in the three cities of Bandung, Indonesia; Iligan City, Philippines, and Phuket, Thailand.

It was also found that the use of social media is not an appropriate place for social interaction between the local government and its people. It should be used for the purpose of providing information to the public, whereas social media should only be used to gather information and not to engage people. Researchers [25] argue that the effective use of social media has led to a troublesome flow of public relations campaigns, so the role of campaign events is to generate publicity instead of a PR campaign. It also facilitates the translation, positioning of the brand and branding of a product that optimized the target audience. It is argued that scholars [26] are examining the use of social media for public relations and government agencies and are arguing on the positive side of social media, which is rooted in both sides of public relations - rhetoric and relational public relations.

Social media management using ground-breaking theoretical principles and in-depth interviews between communication professionals to discover strategies, processes and ideals that underpin strategic communication using social media. The study found that communication experts play a very important role and that the integration of communication is vital to the management of social media communication [27]. Researchers found that issues related to the digital divide were missing, but advertising and journalism in DSM media have always been neglected [28]. In addition, [29] reviewed corporate websites in the US and South Korea and supported other studies that public relations practitioners no longer use the Internet to support public interaction on issues between local government units and the public sector.

The researcher [30] explains that, in a time of crisis communication, the use of the Internet is very useful among websites under a controlled channel where government agencies can effectively communicate to media organizations and the public sector to tell the story that they want to publish among their stakeholders in order to identify public safety in terms of 
publicity and promotion. Social media connections have a significant impact on people using Twitter and serve as a reliable source of public information on issues such as security response and needs in South Korea [31]. In Indonesia, a scholar [32] found that public relations practitioners and journalists are both agents of truth and information for the public to know how to use the Excellence model to support the claim of democracy. Twenty-nine Indonesian municipalities have used Facebook, Twitter and YouTube in Indonesia. Statistically, there is a significant correlation between the use of social media and the popularity of website pages [33].

Blogs, social media and other social media networks continue the practice of public relations and continue to influence conventional media. Research has shown that the majority of respondents are likely to use a different mode of sending messages from different social media convergences, which means that a small number of people have not been able to disseminate information from different media platforms [34]. Government agencies, including small and medium-sized enterprises, have, however, adopted social media for strategic corporate and organizational communication and public relations activities to hear people's voices, members' participation, group dialogue, and community development. Social media experts looked at public tension, mismanagement of social media, control and public governance for better online communities for strategic communication [35].

\subsection{The Concept of Using Social Media in the Government}

The dramatic increase in the use of social media in government agencies has changed over time. There are many responsibilities for the government that have intertwined citizens' participation in public consumption, creating a vast space for social media to ensure accountability among its stakeholders. A study on the use of social media in government agencies between South Korea and the United States of America between 2011 and 2014 found that the majority of government agencies in both countries used social media with a public information officer to disseminate information, followed by a two-way symmetrical persuasive communication model [36].

Recent studies of scholars have revealed the use of the Internet in government agencies to communicate with their constituents, the performance of e-government in government agencies, and the relationship between e-government website use and public-sector engagement. Employees in local government units were, however, strongly convinced of the importance of using social media to engage the public [37].

\subsection{The Concept of Government Public Relations}

A scholar [38] found that Facebook users in western European municipalities were high in numbers but unequal in terms of informants due to a low level of citizen engagement. In addition, the American Red Cross uses social media to build relationships with the public, and has identified barriers to the use of social media as a result of resources, time and personnel. This result was due to limited resources in local government units and other competing interests, and sometimes the budget is not allocated to the government on average [39].

In 2015, three scholars [40] have shown that there is an increasing awareness of the importance of media relations between the types, policies and characteristics of journalists. PR practitioners should understand the needs of the media because there is a difference in quality between government and private- public relations that is significant, public relations in government is better than public relations professionals in private companies in Indonesia. 
Scholars [42] examines the use of social media in local government and the social use of social media by citizens. The findings of the study show that social media, such as Facebook and Twitter, are being used by the government, but officials' perceptions of whether or not they use social media have not predicted the outcome. Public relations in the local government is the best approach in public diplomacy, so the government continues to monitor its stakeholders for development projects. However, the public information office has a significant role to play in the completion of public opinions for its constituents.

\subsection{The Concept of Social Media Communications}

In order to increase the efficiency of LGUs in the public service, social media communication has been used to increase government transparency. The role of the public information office in times of crisis communication is an integral part of the impact of social media on public relations practices. The researcher and company [41] emphasizes issues related to the use of social media for communication crisis information and informs the public through broadcast alerts, and discusses the role of social media in European crisis alerts and other opportunities in the future.

Social media have been identified as having a significant impact on the use of social media in times of crisis, such as media alerts and warning signs in the three European countries (Sweden, Czech Republic, and Spain). A scholar [42] proposes an approach on how to formulate a strategy in times of social media crisis and what implications it might have for a crisis communication strategy (CCS). The researcher considered the most advanced positions on sensitive issues during the negotiation process, using multiple crisis communication experts on a variety of framework crises. As scholars [43] discuss crisis communication strategies, it is very important in any local government whether private and best practices for social media use in a crisis should be aligned with the Crisis Communications Strategic Plan.

Scholar [44] explains how a number of communication strategies have been developed by bringing social media into local government units. For example, Facebook and Twitter use have been considered key social tools and have been widely used by social media to disseminate information to support government programs. However, given that YouTube is too expensive for subscription, due to budgetary constraints, the dissemination of information was not properly channeled to the public. On the contrary, Kent (2013)[45] suggests that the use of social media dialog between people and organizations could make a more effective contribution to equality between constituents.

\section{Methodology}

\subsection{Research Design}

The research design consists of quantitative-descriptive research involving a sample of sixty- eight participants from local government units in CAMANAVA and Batangas Philippines. It is based on a standardized survey questionnaire designed to produce data answered by research questions and to analyze the impact of social media and public relations activities on cohorts between information officers. A scholar[1] recommended that a pilot study be used to test the data collection tool. The pre-test sample of 20 respondents is to determine the reliability of each survey; to request feedback on the survey questionnaire, the form and the wording of the survey; to ensure that respondents understand the context of each 
question and to calculate the time needed to complete the survey questionnaire.

Table 1. Profile of Respondents

\begin{tabular}{ccc}
\hline Sex & Frequency & Percent \\
\hline Male & 49 & 72.1 \\
Female & 19 & 27.9 \\
Total & 68 & 100.0 \\
Age & Frequency & Percent \\
$31-35$ & 16 & 23.5 \\
$36-40$ & 22 & 32.4 \\
$41-45$ & 28 & 41.2 \\
$46-50$ & 2 & 2.9 \\
Total & 68 & 100.0 \\
Employment & Frequency & Percent \\
Contractural & 0 & 0.0 \\
Regular & 68 & 100.0 \\
Total & 68 & 100.0 \\
Employment Status & Frequency & Percent \\
No Eligibility & 33 & 48.5 \\
Sub-Professional & 22 & 32.4 \\
Professional & 13 & 19.1 \\
Total & 68 & 100.0 \\
Highest Educational Attainment & Frequency & Percent \\
College Graduate & 65 & 95.6 \\
MA Graduate & 3 & 4.4 \\
Total & 68 & 100.0 \\
\hline
\end{tabular}

Based on the demographic information provided by the participants, it can be seen that most of the participants were male in terms of sex. As far as age is concerned, it is assumed that the majority of participants in the local government are members of the adult age group. In terms of employment status, participants were regular or permanent government employees, eligible for state civil service, and LGU participants were approved by the CAMANAVA and Batangas City Councils. For this reason, non-eligible government employees were regular employees because the position does not require the eligibility of the civil service.Due to a ban on the conduct of this study, the researcher obtained data from the public information officer with the utmost confidentiality on the basis of ethical considerations in the field of research. Apart from the face-to-face distribution of the survey questionnaire, the online survey was conducted as well as the documentary review, but there was a conflict over time due to the election ban, as this study was conducted and schedules were broken, and the researcher needed to approach the information officers and/or the officer in charge.

\subsection{Ethical Considerations}

Ethical considerations must be taken into account in any research or study to be carried out. The researcher used a number of ethical behaviors in this study. In order to ensure that the information was maintained, no name or personal identification had to be entered in the questionnaire. An initial contact was established by the researcher through a city website, a formal visit, a phone call, to decide whether the identified participant met the requirements and whether they were interested and more than willing to be a respondent, a very appropriate time for the interview was arranged on time and they were told. The letter included the 
objectives of the study and ensured the security of the information provided to the respondents. The researcher provided the pens to be used and provided them with sufficient time to fully read and understand the written statements as they provided the answers. In the end, no audio-video presentations or recordings have been made in the entire study.

\section{Results and Discussion}

The results of this study showed that social media and public relations practices were areas of social media expertise within the government agency known as the Public Information Office. The study examined the impact of social media on public relations practices among public relations officers in CAMANAVA and Batangas. The results of the study are set out below.

RQ1: What is the impact of social media on public relations practices among public information officers in CAMANAVA and Batangas?

The respondents agreed on the indicators referred to above and interpreted 'agreement.' Mean scores on the impact of social media on public relations practices are shown compared to the overall average score. Item 6 has the highest meaning that 'Provides me more access to contact my relatives and friends through social media,' which interprets 'agree.' Item 2 has the second-highest meaning, 'Become my daily companion to communicate with family and friends,' and interprets it as 'agree.' Item 2 has the third-highest meaning, "Become my daily companion to communicate with family and friends," that social media is a matter for public information officers to communicate their close family ties, interpreted as "agree".

Table 2. Impact of social media on public relations practices among public information officers in CAMANAVA and Batangas Province

\begin{tabular}{|c|c|c|c|}
\hline Indicators & Mean & $\begin{array}{c}\text { Std. } \\
\text { Deviation }\end{array}$ & Interpretation \\
\hline $\begin{array}{l}\text { a. Become my first choice of communication with my family, } \\
\text { friends, and colleagues in the government as it offers the } \\
\text { latest information about them. }\end{array}$ & 4.18 & 0.42 & Agree \\
\hline $\begin{array}{l}\text { b. Become my daily companion to communicate with my } \\
\text { family and friends. }\end{array}$ & 4.37 & 0.49 & Agree \\
\hline $\begin{array}{l}\text { c. Offers me more fun and excitement and more interactive } \\
\text { social media than face-to-face communication. }\end{array}$ & 4.28 & 0.51 & Agree \\
\hline d. Offers me to express my inner feelings through social media. & 3.47 & 0.78 & Uncertain \\
\hline $\begin{array}{l}\text { e. Offers more opportunities to invite more friends to chat } \\
\text { online. }\end{array}$ & 4.13 & 0.69 & Agree \\
\hline $\begin{array}{l}\text { f. Offers me more access to contact my relatives and friends } \\
\text { through social media. }\end{array}$ & 4.50 & 0.50 & Strongly Agree \\
\hline $\begin{array}{l}\text { g. Offers me to reduce the cost of communication and open to } \\
\text { worldwide communication. }\end{array}$ & 4.35 & 0.48 & Agree \\
\hline $\begin{array}{l}\text { h. Offers alternative channels such as forums, blogs, chat } \\
\text { rooms, blogging, wikis for discussion. }\end{array}$ & 4.15 & 0.70 & Agree \\
\hline $\begin{array}{l}\text { i. Reduced face-to-face communication with family members, } \\
\text { friends, and colleagues in the office. }\end{array}$ & 4.01 & 0.59 & Agree \\
\hline $\begin{array}{l}\text { j. Offers a stronger relationship with family, friends, and } \\
\text { colleagues in the office which able to keep in touch any time } \\
\text { of the day through social media. }\end{array}$ & 4.43 & 0.61 & Agree \\
\hline Composite Mean & 4.29 & 0.46 & Agree \\
\hline
\end{tabular}


This result is consistent with the study by researchers in 2018 [49] that the most popular social media platforms include Facebook, Twitter, Instagram, Snapchat, and WhatsApp, which continue to grow worldwide due to their impact on human communication. While Facebook also establishes relationships, content sharing, opinions, entertainment and communication with the constituents of the government [46]. It is also one of the most popular Social Networking Sites (SNS) with 1,71 billion active members and users in 2016 [47].

Ho1: The impact of social media on public relations practices among public information officers is significant.

RQ2: What part ofpublic relations activities in the provinces of CAMANAVA and Batangas has been influenced by public information on social media?

The composite average shows that the respondents agreed with the indicators referred to above and interpreted 'agreement.' The mean scores on the impact of social media on public relations practices are shown in the table compared to the overall average score of the sample. Item number 2 has the highest mean, "As a public relations officer, I often use social media sites such as Facebook, Twitter, Google, Pinterest, Instagram to share and send messages to clients, friends and followers" Item \#2 has the highest mean and interprets "agree."

In 2018, a scholar [48] pointed out that growing areas of professional public relations must be under their belt as digital skills such as Facebook, Twitter and Instagram have grown considerably over the years. With regard to the use of social media by public information officers to monitor feedback, disseminate information, campaigns and events [49], [50], it has been disclosed that online customer service allows users to foster some of these relationships in person with organizations in real time.

Ho2: The influence of social media on public relations practices is significant.

Table 3. Influence of social media on public relations practices

\begin{tabular}{|c|c|c|c|}
\hline Indicators & Mean & $\begin{array}{c}\text { Std } \\
\text { Deviation }\end{array}$ & Interpretation \\
\hline $\begin{array}{l}\text { a. Public relations practices are more visible now rather than } \\
\text { the previous one due to social media in creating an } \\
\text { awareness campaign in the local government units. }\end{array}$ & 4.34 & 0.48 & Agree \\
\hline $\begin{array}{l}\text { b. As a public relations officer, I often use social media sites } \\
\text { such as Facebook, Twitter, Google, Pinterest, Instagram } \\
\text { to share and send messages to clients, friends, and } \\
\text { followers. }\end{array}$ & 4.49 & 0.50 & Agree \\
\hline $\begin{array}{l}\text { c. Social media helps me to improve media monitoring in } \\
\text { the local government units by using search engines. }\end{array}$ & 4.31 & 0.47 & Agree \\
\hline $\begin{array}{l}\text { d. Social media is the best option as a public information } \\
\text { officer to disseminate public relations events and } \\
\text { information education campaigns in the community. }\end{array}$ & 4.32 & 0.47 & Agree \\
\hline $\begin{array}{l}\text { e. I often visit social media sites to monitor feedbacks from } \\
\text { public information campaigns and events. }\end{array}$ & 4.03 & 0.60 & Agree \\
\hline $\begin{array}{l}\text { f. Public information officers can develop more interactive } \\
\text { and intimate relationships by using social media. }\end{array}$ & 4.16 & 0.68 & Agree \\
\hline $\begin{array}{l}\text { g. Public information officers can ask substantial questions } \\
\text { and get feedback from the public sector. }\end{array}$ & 4.16 & 0.68 & Agree \\
\hline $\begin{array}{l}\text { h. Public information officers may share a link of press } \\
\text { releases on social media sites to publish articles without } \\
\text { filtering the content in the online }\end{array}$ & 4.29 & 0.49 & Agree \\
\hline
\end{tabular}




\begin{tabular}{lllcc}
\hline \multicolumn{1}{c}{ Indicators } & Mean & \multicolumn{1}{c}{$\begin{array}{c}\text { Std } \\
\text { Deviation }\end{array}$} & Interpretation \\
\hline i. & $\begin{array}{l}\text { newspapers. } \\
\text { j. } \begin{array}{l}\text { Public relations officers may use social media (i.e. } \\
\text { Facebook \& Twitter) to remind the public during } \\
\text { catastrophe and resilience by posting status, pics, and } \\
\text { vids. }\end{array}\end{array}$ & 0.53 & Agree \\
k. Public relations officers can assist the public sector to a \\
$\begin{array}{l}\text { wider spectrum of the audience at no cost compared to } \\
\text { traditional media. }\end{array}$
\end{tabular}

RQ3: To what extent the use of social media has impacted the personal lives of public information officers in the local government.

Table 4. The extent of uses of social media affected the personal lives of public information officers in the local government units

\begin{tabular}{|c|c|c|c|c|}
\hline & $\begin{array}{l}\text { Indicators } \\
\end{array}$ & Mean & Std. Deviation & Interpretation \\
\hline a. & $\begin{array}{l}\text { My public information practice is enhanced by } \\
\text { the transformation of social media. }\end{array}$ & 4.22 & 0.42 & Agree \\
\hline & $\begin{array}{l}\text { My public information practice expands social } \\
\text { media networks from the number of friends in } \\
\text { the community. }\end{array}$ & 4.19 & 0.40 & Agree \\
\hline & $\begin{array}{l}\text { My public information practice in the local } \\
\text { government units enhanced my reputation in the } \\
\text { community. }\end{array}$ & 4.16 & 0.68 & Agree \\
\hline & $\begin{array}{l}\text { My public information practice improves } \\
\text { internal relations with the mayor, members of } \\
\text { Sangguniang Bayan, and department heads in } \\
\text { the local government. }\end{array}$ & 4.25 & 0.47 & Agree \\
\hline & $\begin{array}{l}\text { My public information practice maintains } \\
\text { positive relations with the community. }\end{array}$ & 4.06 & 0.79 & Agree \\
\hline f. & $\begin{array}{l}\text { My public information practice resolves the } \\
\text { problems and issues in the office. }\end{array}$ & 3.50 & 0.74 & Agree \\
\hline & $\begin{array}{l}\text { My public information practice allows me to } \\
\text { respond immediately to criticisms in the local } \\
\text { government units. }\end{array}$ & 4.00 & 0.60 & Agree \\
\hline h. & $\begin{array}{l}\text { My public information practice has changed the } \\
\text { way to communicate with the target audience. }\end{array}$ & 3.88 & 0.70 & Agree \\
\hline & $\begin{array}{l}\text { My public information practice exposes me to } \\
\text { new media technology to create a spectacle to } \\
\text { increase the number of people. }\end{array}$ & 4.06 & 0.57 & Agree \\
\hline $\mathrm{j}$. & $\begin{array}{l}\text { I need more technical skills in the areas of web } \\
\text { publishing, new software operation, search } \\
\text { engine, online security, and data privacy act as } \\
\text { public information officer. }\end{array}$ & 3.87 & 0.73 & Agree \\
\hline & $\begin{array}{l}\text { I am doubtful of using social media before } \\
\text { therefore I do not use it at all. }\end{array}$ & 3.00 & 0.73 & Uncertain \\
\hline & $\begin{array}{l}\text { I tried using social media before but I'm not } \\
\text { comfortable using it. }\end{array}$ & 2.88 & 0.61 & Uncertain \\
\hline & $\begin{array}{l}\text { I am using social media as a part of my regular } \\
\text { tasks in the office and career development. }\end{array}$ & 4.15 & 0.47 & Agree \\
\hline
\end{tabular}




\begin{tabular}{llccc}
\hline \multicolumn{1}{c}{ Indicators } & Mean & Std. Deviation & Interpretation \\
\hline $\mathrm{n} . \quad \begin{array}{l}\text { I consider myself an advanced social media user } \\
\text { in the public information office. }\end{array}$ & 4.12 & 0.44 & Agree \\
$\begin{array}{l}\text { o. I consider myself a social media specialist for } \\
\text { my profession as a public information officer. }\end{array}$ & 3.69 & 0.76 & Agree \\
$\begin{array}{l}\text { Composite Mean } \\
\text { Congree }\end{array}$ \\
\hline
\end{tabular}

The extent to which social media are used by public information officers in local government units (LGUs) where demographic information of respondents such as sex, age, eligibility and local government units is considered and assumptions accepted. Sex, age, man. Eligibility, higher educational attainment, is interpreted as "not a significant correlation, and the hypothesis is accepted". The extent of the use of social media affecting the lives of public information officers in local government units confirms in the study that it should be used to provide information to the public, whereas social media should only be used to gather information and not to engage people in decision-making [51].

Ho3:The extent to which the uses of social media affected the personal lives of public information officers in the local government units is significant.

Table 5. Correlations between impact, influence, and extent of use of social media when the demographic profile of respondents are considered

\begin{tabular}{|c|c|c|c|c|}
\hline \multicolumn{2}{|c|}{ Demographic Profile } & Impact & Influence & Extent \\
\hline \multirow{5}{*}{ Sex } & Correlation & .173 & .222 & -.171 \\
\hline & Coefficient & & & \\
\hline & Sig. (2- & .157 & .069 & .162 \\
\hline & tailed) & Not Significant & Not Significant & Not \\
\hline & $\begin{array}{l}\text { Interpretation } \\
\text { Decision }\end{array}$ & Accept Ho & Accept Ho & $\begin{array}{l}\text { Significant } \\
\text { Accept Ho }\end{array}$ \\
\hline \multirow{4}{*}{ Age } & Correlation & -.128 & -.069 & .015 \\
\hline & $\begin{array}{l}\text { Coefficient Sig. } \\
\text { (2- }\end{array}$ & .299 & .576 & .902 \\
\hline & $\begin{array}{l}\text { tailed) } \\
\text { Interpretation } \\
\text { Decision }\end{array}$ & $\begin{array}{l}\text { Not Significant } \\
\text { Accept Ho }\end{array}$ & $\begin{array}{l}\text { Not Significant } \\
\text { Accept Ho }\end{array}$ & $\begin{array}{c}\text { Not } \\
\text { Significant } \\
\text { Accept Ho }\end{array}$ \\
\hline & Correlation & -.055 & -.064 & -.004 \\
\hline \multirow{4}{*}{ CSC Eligibility } & Coefficient & & & \\
\hline & Sig. (2- & .653 & .602 & .971 \\
\hline & tailed) & Not Significant & Not Significant & Not \\
\hline & $\begin{array}{l}\text { Interpretation } \\
\text { Decision }\end{array}$ & Accept Ho & Accept Ho & $\begin{array}{l}\text { Significant } \\
\text { Accept Ho }\end{array}$ \\
\hline \multirow{4}{*}{$\begin{array}{c}\text { Highest Educational } \\
\text { Attainment }\end{array}$} & Correlation & .176 & $.321 * *$ & .094 \\
\hline & $\begin{array}{l}\text { Coefficient } \\
\text { Sig (2tailed) }\end{array}$ & .152 & .008 & 444 \\
\hline & Interpretation & Not Significant & Significant Reject & Not \\
\hline & Decision & Accept Ho & $\mathrm{Ho}$ & $\begin{array}{l}\text { Significant } \\
\text { Accept Ho }\end{array}$ \\
\hline \multirow{4}{*}{$\begin{array}{l}\text { Time Spent in using } \\
\text { Social Media }\end{array}$} & Correlation & $.278^{*}$ & .220 & -.039 \\
\hline & Coefficient & & & \\
\hline & Sig. (2- & .022 & .071 & .754 \\
\hline & Interpretation & Significant & Not Significant & $\begin{array}{c}\text { Not } \\
\text { Significant }\end{array}$ \\
\hline
\end{tabular}




\begin{tabular}{ccccc}
\hline \multicolumn{2}{c}{ Demographic Profile } & Impact & Influence & Extent \\
\hline & Decision & Reject Ho & Accept Ho & Accept Ho \\
& $\begin{array}{c}\text { Correlation } \\
\text { Coefficient }\end{array}$ & -.095 & -.069 & -.050 \\
Local Government & Sig. (2tailed) & .439 & .574 & .687 \\
Unit & $\begin{array}{c}\text { Interpretation } \\
\text { Decision }\end{array}$ & $\begin{array}{c}\text { Not Significant } \\
\text { Accept Ho }\end{array}$ & $\begin{array}{c}\text { Not Significant } \\
\text { Accept Ho }\end{array}$ & $\begin{array}{c}\text { Not } \\
\text { Significant } \\
\text { Accept Ho }\end{array}$ \\
\hline
\end{tabular}

**. Correlation is significant at the 0.01 level (2-tailed).

*. Correlation is significant at the 0.05 level (2-tailed).

RQ4: Is there a significant correlation between the impact of social media on public relations practices, the gender and demographic profile of respondents, such as age, eligibility, time spent using social media, and local government units?

Statistically, there is no significant correlation between the impact of social media on public relations, the "no significant" interpretation and the assumption. It shows that the age correlation coefficient is interpreted as "not significant" and accepts the hypothesis. The eligibility of public information officers in the local government has a correlation coefficient that is interpreted as "not significant" and the hypothesis is "acceptable."

Ho4: There a significant correlation between the impact of social media on public relations practices, the gender and demographic profile of respondents, such as age, eligibility, time spent using social media, and local government units.

\section{Conclusions}

Based on the overall results and discussions, the impact of social media on public relations, the influence of social media among public information officials living in local government units and the extent to which social media are used in online public relations, the number of social media platforms is increasing and is being reached as an effective tool to fulfill and fulfill the role of public information.

Social media and public relations practices in LGUs continue to rely on one-way communication, such as Facebook, Twitter, Instagram, etc., resulting in 68 participants. It also shows that social media and public relations have used all four public relations models, while local government units use public information patterns and other communication patterns to communicate with citizens in particular cities in CAMANAVA and Batangas, Philippines.

\section{Limitation and Further Research}

This study is limited to local government units that are already implementing the widespread use of social media for the distribution of information and the use of e-government systems to connect with the public to create a way of life. As far as research methods are concerned, it is recommended that further research be carried out using a mixed-method to find more comprehensive results. Research using a quantitative-descriptive approach is conducted through in-depth interviews using other approaches, such as case studies. 


\section{References}

[1] Mahajan-Cusack, L.: The impact of social media on local government transparency and citizen engagement. Unpublished dissertation. The State University of New Jersey. (2016)

[2] Warren, A., Sulaiman A. \& Jaafar, N.: Social media effects on fostering online civic engagement and building citizen trust in institutions. Government Information Quarterly, Vol 31, pp. 291-301 (2014)

[3] Inya, A. E.: Influence of social media on public relations practices in universities in South-East Nigeria. Global Journal of Human Social Science: Arts and HumanitiesPsychology, Vol. 17 No. 3, pp. 45-52. (2017)

[4] Spurrell, D.: An opportunity or a threat? How the local government uses social media today. (2012)

[5] Karakiza, M.: The impact of social media in the public sector. Procedia Social Media and Behavioral Sciences, Vol. 175, pp. 384-392. (2015)

[6] Hansen, D.L., Shneiderman, B. \& Smith, M.A.: Analyzing social media networks with NodeXL: Insights from a connected world. Burlington: MA: Morgan Kaufmann. (2011)

[7] Dixon, B.: Towards e-government 2.0: An assessment of where e-government 2.0 is and where it is headed. Public Administration and Management, Vol. 15, No. 2, pp. 418-454. (2010)

[8] Hopkins, A. E.: Government public relations: Public diplomacy or propaganda? Inquiries: Social Science, Arts \& Humanities, Vol. 7, No. 3, pp. 1-3. (2015)

[9] Porter, B. YouTube offers digital town hall meetings. Corridor Business Journal, Vol. 7, No. 27, p. 10. (2011)

[10] Yankah, K.: Government public relations in West Africa: Propaganda or development tool: The case of Ghana's Ministry of Information. Bled Com 2010 Proceedings. (2010)

[11] Roengtam, S., Nurmandi, A., Almarez, D. N. \& Kholid, A.: Does social media transform the city government? A case study of three ASEAN cities (Bandung, Indonesia; Iligan City, Philippines \& Phuket, Thailand). Transforming Government: People, Process and Policy, Vol.11, No.3, pp. 343-376. (2017)

[12] Foundation for Media Alternatives.: Social media and privacy: The Philippine experience. (2015)

[13] City Public Affairs and Information Office (CPIAO): Public Information Office. (2018)

[14] Roengtam, S., Nurmandi, A., Almarez, D. N. \& Kholid, A.: Does social media transform the city government? A case study of three ASEAN cities (Bandung, Indonesia; Iligan City, Philippines \& Phuket, Thailand). Transforming Government: People, Process and Policy, Vol.11, No.3, pp. 343-376. (2017)

[15] City Government of Malabon.: The official website of Malabon City: Malabon Online Information Center. (2018)

[16] Navotas City@Navotas_City.: Official Twitter Account of Navotas City. (2019)

[17] The Official Website of the City Government of Valenzuela. : Tayo na Valenzuela. (2018)

[18] Valenzuela City $11 @$ Valenzuela city. : City Government of Valenzuela: Official Twitter Account of the City Government of Valenzuela: Tayo na, Valenzuela! (2018)

[19] Padura, V.R., Bermas, N. \& Padayao, D.: Promoting effective information 
management through academic partnership; the case of Batangas Province, Philippines. Chua, T.-E., L.M. Chou, G. Jacinto, S.A. Ross, and D. Bonga. (Eds). Local Contributions to Global Sustainable Agenda: Case Studies in Integrated Coastal Management in the East Asian Seas Region. Partnerships in Environmental Management for the Seas of East Asia (PEMSEA) and Coastal Management Center (CMC), Quezon City, Philippines. (2018)

[20] Batangas City Official Website.: Batangas City: Industrial Port City of CALABARZON: Public Information Office organizational chart. (2018)

[21] Dunbar, R.I., Arnaboldi, V., Conti, M. \& Passarella, A.: The structure of online social networks mirrors those in the offline world. Social Networks, Vol. 43, No. 5, pp. 3947. (2015)

[22] Awofadeju, P.O. \& Ewuola, P.O: Impact of social media on public relations practice. Journal of Social Sciences and Humanities Research, Vol. 4, No. 5, pp. 65-85. (2019)

[23] Jiang, H., Lou, Y. \& Kulemeka, O.: Strategic social media use in public relations: Professionals perceived social media impact, leadership behaviors, and work-life conflict. International Journal of Strategic Communication, Vo. 11,No. 1. (2018).

[24] Roengtam, S., Nurmandi, A., Almarez, D. N. \& Kholid, A.: Does social media transform the city government? A case study of three ASEAN cities (Bandung, Indonesia; Iligan City, Philippines \& Phuket, Thailand). Transforming Government: People, Process and Policy, Vol.11, No.3, pp. 343376. (2017)

[25] Allagui, I. \& Breslow, H.: Social media for public relations: Lessons from four effective cases. Public Relations Review, Vol. 42, No. 1, pp. 20-30. (2016)

[26] Valentini, C.: Is using social media good for the public relations profession? A critical reflection. Public Relations Review, Vol. 41 No. 2, pp. 170-177. (2015)

[27] Smith, B. G. Situated ideals in strategic social media.: Applying grounded practical theory in a case of successful media management. International Journal of Strategic Communication, Vol. 9 No. 4, pp. 272-292. (2015)

[28] Vercic, D., Vercic, A. T. \& Sriramesh, K.: Looking for a digital in public relations. Public Relations Review, 41(2), 142-152. (2015).

[29] Jo, S. \& Jung, J.: A cross-cultural study of the world wide web and public relations. Corporate Communications: An International Journal, Vol. 10, pp. 24-40. (2005)

[30] James, M. A.: Review of the impact of new media on public relations: Challenges for terrain, practice, and education. The Asia Pacific Public Relations Journal, Vol. 8, pp. 137-148. (2014)

[31] Khan, G., Young Yoon, H., Kim, J., and Woo Park, H.: From e-government to social government: Twitter use by Korea's central government. Online Information Review, Vol. 38, No.1, pp. 95-113. (2014)

[32] Kriyantono, R.: The excellence and news objectivity model as the models for the harmonious relationship between public relations officers and journalists. Journal of Media \& Mass Communication, Vol. 1 No. 1, pp. 39-42. (2014).

[33] Anshori, M. A. I. A.: Effect of social media on website city government in Indonesia. InternationalConference on Internet Studies, August 16-17, Singapore. (2014)

[34] Wright, D. K. \& Hinson, M. D.: An updated examination of social and emerging media use in public relations practice: A longitudinal analysis between 2006 and 2014. Public Relations Journal, Vol. 8 No. 2. (2014)

[35] Macnamara, J.: Australian Centre for Public Communication. Social media strategy and governance: Gaps, risks, and opportunities. (2011).

[36] Lee, M. J. \& Cho, H. Uses of social media in government agencies: Content analyses 
of PR models, strategies, and tactics comparison between South Korea and the United States of America in 2011 and 2014. Journal of Public Affairs, Vol. 18 No. 2. (2017)

[37] Nica, E., Popescu, G. H., Nicolaescu, E. \& Constantin, V. D.: The effectiveness of social media implementation at local government levels. Transylvanian Review of Administrative Sciences. (2015)

[38] Ratkai, M.: Corporate social media is a tool for voluntary reporting, transparency, and stakeholder engagement in Western European local governments. Unpublished dissertation. Universidad de Huelva. (2014)

[39] Graham, M. W.: Government communication in the digital age: Social media's effect on local government public relations. Public Relations Inquiry, Vol. 3 No.3, pp. 361376. (2014).

[40] Syahri, M. A., Kriyantono, R. \& Nasution, Z.: An explanative study on the different perceptions of journalists toward media relations of government and private-public relations. Asian Journal of Humanities and Social Sciences, Vol. 3 No. 1, pp/ 36-47. (2015)

[41] Brynielsson, J., Granasen, M., Lindquist, S., Quijano, M. N., Nilsson, S. \& Trnka, J.: Informing crisis alerts using social media: Best practices and proof of concern. Journal of Contingencies and Crisis Management, Vol. 26 No. 1. (2017)

[42] Zhao, H.: The impacts of contextual factors on social media crises: Implications for crisis communication strategy selection. International Journal of Strategic Communication, Vol. 11 No.1, pp. 42-60. (2017)

[43] Lin, X., Spence, P. R., Sellnow, T. L. \& Lachlan, K. A.: Crisis communication, learning, and responding: Best practices in social media. Computers in Human Behavior, Vol. 65, pp. 601-605. (2016)

[44] Graham, M. \& Avery, E. J.: Government public relations and social media: An analysis of the perceptions and trends of social media use at the local government level. Public Relations Journal, Vol. 7 No.4, pp. 1-21. (2013)

[45] Kent, M. L.: Using social media dialogically: Public relations role in reviving democracy. Public Relations Review, Vol. 39 No. 4, pp. 337-345. (2013)

[46] Woo, S. \& Lee, J.: Telematics and informatics as a comparative study of KakaoStory and Facebook: Focusing on use patterns and use motives. Telematics and Informatics, Vol. 34No. 1, pp. 220-229. (2017)

[47] Chao, C. \& Keung, N.: Predicting social capital on Facebook: The implications of use intensity, perceived content desirability, and Facebook-enabled communication practices',. Computers in Human Behavior Vol. 72, pp. 259-268. (2017)

[48] Freberg K., Kim C.M.: Social media education: Industry leader recommendations for curriculum and faculty competencies. Journalism \& Mass Communication Educator, Vol. 73 No. 4, pp. 379-391. (2018)

[49] Bowen S.A.: Using classic social media cases to distill ethical guidelines for digital engagement. Journal of Mass Media Ethics, Vol. 28 No. 2, pp. 119-133. (2013)

[50] Sisson D.C. Control mutuality, social media, and organization-public relationships: A study of local animal welfare organizations' donors. Public Relations Review, Vol. 43 No.1, pp. 179-189. (2017)

[51] Roengtam, S., Nurmandi, A., Almarez, D. N. \& Kholid, A.: Does social media transform the city government? A case study of three ASEAN cities (Bandung, Indonesia; Iligan City, Philippines \& Phuket, Thailand). Transforming Government: People, Process and Policy, Vol. 11 No. 3, pp. 343376. . (2017)

[52] Sutherland, K. Freberg, K., Driver, C. \& Khattab, U.: Public relations and customer 
service: Employer perspectives of social media proficiency. Public Relation Review, Vol. 46 No. 4, p. 01954. (2020)

[53] Gesualdi, M.: Revisiting the relationship between public relations and marketing: Encroachment and social media. Public Relations Review, Vol. 45 No.5, pp. 386-394. (2019) 